\title{
Small subunit rRNA gene sequences of Aeromonas salmonicida subsp. smithia and Haemophilus piscium reveal pronounced similarities with $A$. salmonicida subsp. salmonicida
}

\author{
Jacinta M. Thornton ${ }^{1}$, Dawn A. Austin ${ }^{2}$, Brian Austin ${ }^{2}$, Richard Powell ${ }^{1, *}$ \\ 'Department of Microbiology, National University of Ireland, Galway, Ireland \\ ${ }^{2}$ Department of Biological Sciences, Heriot-Watt University, Riccarton, Edinburgh EH14 4AS, Scotland, UK
}

\begin{abstract}
The small subunit ribosomal RNA (SSU rRNA) encoding genes from reference strains of Aeromonas salmonicida subsp. smithia and Haemophilus piscium were amplified by polymerase chain reaction and cloned into Escherichia coli cells. Almost the entire SSU rRNA gene sequence (1505 nucleotides) from both organisms was determined. These DNA sequences were compared with those previously described from $A$. salmonicida subsp. salmonicida, subsp. achromogenes and subsp. masoucida. This genetic analysis revealed that $A$. salmonicida subsp. smithia and $H$. piscium showed 99.4 and $99.6 \%$ SSU IRNA gene sequence identity, respectively, with A. salmonicida subsp. salmonicida.
\end{abstract}

KEY WORDS: Aeromonas salmonicida - Haemophilus piscium - Ribosomal RNA genes

In the 1950s, phenetic analysis resulted in a detailed description of Aeromonas salmonicida, the bacterium associated with furunculosis disease of salmonids (Griffin 1953, Snieszko 1957). Subsequently, analysis of strains with some aberrant traits redefined this taxon into 3 subspecies (Schubert 1974), i.e. A. salmonicida subsp. saimonicida, subsp. achromogenes (Smith 1963), and subsp. masoucida (Kimura 1969). More recently, a further subspecies, subsp. smithia (Austin et al. 1989), has been described. Also of note, Haemophilus piscium, the etiological agent of ulcer disease in salmonid species (Snieszko et al. 1950), is commonly thought to represent another aberrant member of $A$. salmonicida (Paterson et al. 1980, Trust et al. 1980), a view reinforced by Austin et al. (1998).

In a recent characterization study that included reference strains for Aeromonas salmonicida subsp.

\footnotetext{
- Addressee for correspondence.

E-mail: richard.powell@nuigalway.ie
}

salmonicida, subsp. achromogenes, subsp. masoucida, and subsp. smithia and Haemophils piscium, all strains were separated on the basis of ribotype; only subsp. achromogenes and $H$. piscium were grouped together in a biochemical analysis, and only subsp. masoucida and subsp. achromogenes were grouped together in a polymerase chain reaction (PCR) analysis (Austin et al. 1998). In light of these results, we sought to examine these strains by determining the nucleotide sequences of their respective small subunit ribosomal RNA (SSU rRNA) encoding genes. SSU rRNA gene sequences have been shown to be useful for the determination of either close or distant genealogical relationships (Woese 1987), and the SSU rRNA gene sequences for A. salmonicida subsp. salmonicida, subsp. achromogenes and subsp. masoucida have already been described (Martinez-Murcia et al. 1992). Here, we report the SSU rRNA gene sequences of $A$. salmonicida subsp. smithia and $H$. piscium and a comparative sequence analysis with the SSU IRNA genes of $A$. salmonicida subsp. salmonicida, subsp. achromogenes, and subsp. masoucida

Materials and methods. Origin and growth of strains: The type strain Aeromonas salmonicida subsp. smithia (CCM 4103) was obtained from the Czechoslovakian Collection of Microorganisms, Brno, Czech Republic. The Haemophilus piscium strain (NCIMB 1952) was obtained from the National Collection of Industrial and Marine Bacteria, Aberdeen, Scotland. It should be noted that an authentic type strain of $H$. piscium is not available in any culture collection. CCM 4103 was cultivated on colombia base agar (Oxoid, Unipath Ltd, Hampshire, UK) supplemented with $7 \%$ human blood, whereas the $H$. piscium strain was grown on tryptone soya agar supplemented with $1 \%$ 
$\mathrm{NaCl}$ and $0.0002 \%$ cocarboxylase (Sigma Chemical Co., St. Louis, USA). Both strains required 2 to $3 \mathrm{~d}$ growth at $22^{\circ} \mathrm{C}$.

Bacterial DNA extraction: Bacterial biomass from $10 \mathrm{ml}$ cultures was collected by centrifugation and washed in $1 \mathrm{ml}$ of sterile $\mathrm{H}_{2} \mathrm{O}$, followed by centrifugation for 5 min at $9650 \times g$ (MSE Micro Centaur, Sanyo, UK) and resuspension in $400 \mu \mathrm{l}$ TE buffer (10 mM Tris$\mathrm{HCl}, 1 \mathrm{mM}$ EDTA, $\mathrm{pH}$ 8.0). The cells were then lysed by the addition of $200 \mu \mathrm{l}$ of $10 \mathrm{mg} \mathrm{ml}^{-1}$ lysozyme (Boehringer Mannheim GmbH, Germany) and incubation at $37^{\circ} \mathrm{C}$ for $60 \mathrm{~min}$. The preparation was then incubated for $10 \mathrm{~min}$ with $40 \mu \mathrm{l}$ of $10 \mathrm{mg} \mathrm{ml}^{-1}$ proteinase $\mathrm{K}$ (Boehringer Mannheim) at room temperature, followed by the addition of sodium dodecyl sulphate (SDS) to a final concentration of $1 \%$ and incubation at room temperature until the preparation was clear. Eighty $\mu$ of $0.5 \mathrm{M}$ EDTA was added, and mixed by gentle agitation and the solution was deproteinated by sequential phenol and chloroform isoamyl alcohol (24:1 vol/vol) extraction. The genomic DNA was precipitated in ethanol and resuspended in sterile $\mathrm{H}_{2} \mathrm{O}$. The DNA concentration was estimated by visual comparison with the standard DNA size markers after electrophoresis through $1 \%$ agarose (BioGene Ltd, Cambridgeshire, UK) TAE (tris-acetate EDTA) gels stained with $0.5 \mu \mathrm{g}$ $\mathrm{ml}^{-1}$ ethidium bromide (Sigma Chemical Co.).

PCR amplification and cloning of the SSU rRNA genes: The designation and sequences of the PCR primers and their reference positions on alignments of SSU rRNA gene sequences are EB, 5'-GAGTTTGATCCTGGCTCAG-3' (bases 3-25) and UN, 5'-ACGGNWACCTTGTTACGAGTT-3' (bases 1423-1402) (Standard International Union of Pure and Applied Chemistry nomenclature: $\mathrm{N}$ is $\mathrm{G}, \mathrm{A}, \mathrm{T}$ or $\mathrm{C} ; \mathrm{W}$ is $\mathrm{A}$ or $\mathrm{T}$ ). Both PCR primers are described as being specific for most bacteria (Lane 1991). The $50 \mu$ l reaction contained $1 \times$ $\mathrm{NH}_{4}$ buffer and $1.5 \mathrm{mM} \mathrm{MgCl}$ (Biotaq, Bioline UK Ltd), $200 \mu \mathrm{M}$ dNTPs (BioGene Ltd), 1 U Taq DNA polymerase (Biotaq, Bioline UK Ltd), 170 pmol of primer EB, 157 pmol of primer UN and 20 ng of genomic DNA, overlaid with $30 \mu \mathrm{l}$ of mineral oil. Negative controls containing no DNA were included. The reactions were then amplified using a TRIO-thermoblock thermocycler (Biometra GmbH, Göttingen, Germany) through 30 cycles of $1 \mathrm{~min}$ at $94^{\circ} \mathrm{C}, 1 \mathrm{~min}$ at $52^{\circ} \mathrm{C}$ and $1 \mathrm{~min}$ at $72^{\circ} \mathrm{C}$ followed by a final extension of $5 \mathrm{~min}$ at $72^{\circ} \mathrm{C}$. Five $\mu$ aliquots of the amplification products were analysed by electrophoresis through $1 \%$ agarose TAE gels stained with $0.5 \mu \mathrm{g} \mathrm{m} \mathrm{m}^{-1}$ ethidium bromide. The PCR products were purified using the Geneclean II kit (BIO 101 Inc., Vista, CA, USA) according to the manufacturers instructions. The purified PCR products were cloned using the TA cloning system according to the manufacturers protocol (Invitrogen Corp., San Diego, CA, USA).

DNA sequences and alignment: Initially the SSU rRNA gene sequences of Aeromonas salmonicida subsp. smithia and Haemophilus piscium were determined using the ABI 373 automatic DNA sequencer (Perkin Elmer, Applied Biosystems Inc., CA, USA) using the dye terminator kit supplied by Applied Biosystems. The DNA sequences were then aligned using the ClustalW programme (Higgins \& Sharp 1988) with the SSU rRNA gene sequences retrieved from the GenBank database of $A$. salmonicida subsp. salmonicida NCIMB 1102 (accession no. X60405) and the identical SSU rRNA gene sequences of subsp. achromogenes NCIMB 1110 and subsp. masoucida NCIMB 2020 (X60406). All sequence variations between subsp. smithia and $H$. piscium and the database entries were checked by manual DNA sequencing using the T7 sequencing kit (Pharmacia, Uppsala, Sweden) and variant nucleotides were either corrected or confirmed. Both strands were sequenced in their entirety by both automated and manual methods. The sequences reported in this study have been deposited in the GenBank database under the accession nos. AJ009859 (subsp. smithia) and AJ009860 ( $H$. piscium).

Results and discussion. Using the PCR primers UN and EB, a DNA fragment of approximately 1500 nucleotides in length was amplified from each of the 2 strains studied. Following DNA sequencing, a total of 1505 unambiguous nucleotide positions in the SSU rRNA gene from Aeromonas salmonicida subsp. smithia and Haemophlus piscium were determined. Fig. 1 shows a comparative nucleotide sequence alignment between these 2 sequences and the maximum available 1503 nucleotides of the SSU rRNA gene sequences of $A$. salmonicida subsp, salmonicida (NCIMB 1102), subsp. achromogenes (NCIMB 1110) and subsp. masoucida (NCIMB 2020). The analysis revealed very high levels of SSU rRNA gene sequence similarity. A. salmonicida subsp. smithia (CCM 4103) differed from $A$. salmonicida subsp. salmonicida at only 9 sites (i.e. $99.4 \%$ similarity) while $H$. piscium (NCIMB 1952) differed from the same type strain at only 6 sites (i.e. $99.6 \%$ similarity). All the reference

Fig. 1 SSU rRNA gene nucleotide sequence alignment. All sequences are compared to the SSU rRNA gene sequence of Aeromonas salmonicida subsp. salmonicida and only variant nucleotides are noted. (-) no homologous nucleotide at this position, $(\cdot)$ an identical nucleotide at this position 
A. salmonicida subsp. salmonicida

A. salmonicida subsp. achromogenes

A. salmonicida subsp. masoucida

A. salmonicida subsp. smithia Haemophilus piscium
GAGTTTGATCATGGCTCAGATTGAACGCTGGCGGCAGGCCTAACACATGCAAGTCGAGCGGCAGCGGGAAR

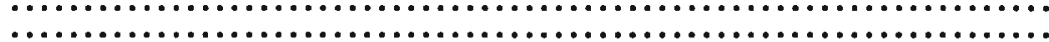

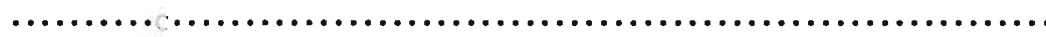

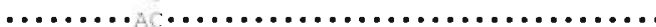

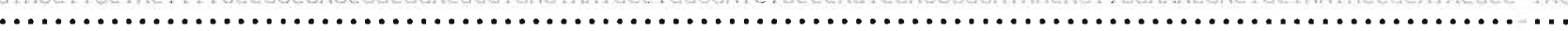

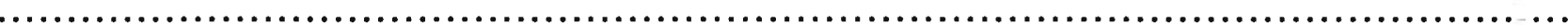

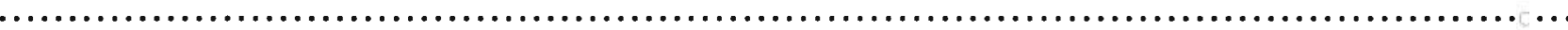

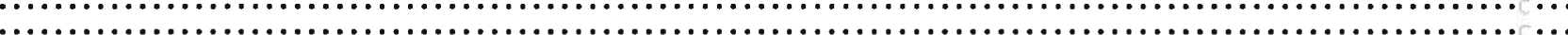

GGGGGAAAGGAGGGGACCTTCGGGCCTTTCGCGATTGGATGAACCCAGGTGGGATTAGCTAGTTGGTGGGGTAATGGCTCACCAAGGCGACGATCCCTAGCTGGTCTGAGA

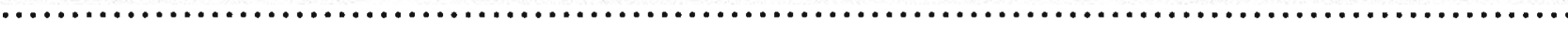

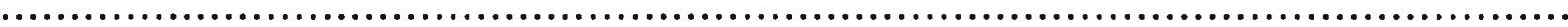

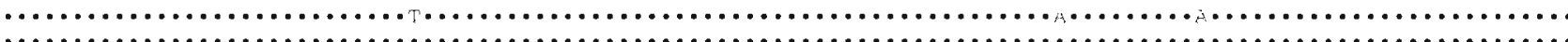

GATGATCAGCCACACTGGAACTGAGACACGGTCCAGACTCCTACGGGAGGCAGCAGTGGGGAATATAGCACAATGGGGGAAACCCTGATGCAGCCATGCCGCGTGTGTGAAG

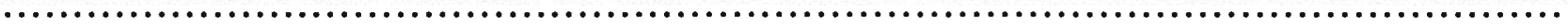

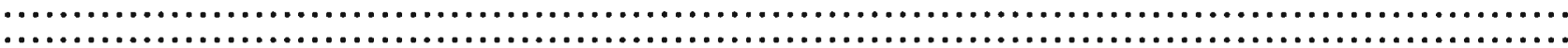
(1)

AAGGCCTTCGGGTTGTAAAGCACTTTCAGCGAGGAGGAAAGGTTGGCGCCTAATACGTGTCAACTGTGACGTTACTCGCAGAAGAAGCACCGGCTAACTCCGTGCCAGCAGC

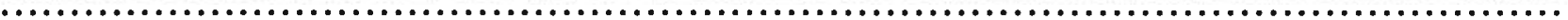

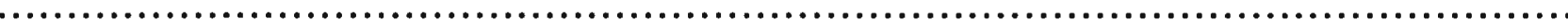

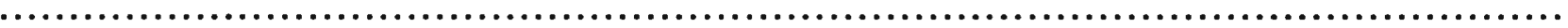

CGCGGTAATACGGAGGGTGCAAGCGTTAATCGGAATTACTGGGGTAAAGCGCACGCAGGCGGTIGGATAAGTTAGATGTGAAAGCCCCGGGCTCAACCTGGGAATTGCAT

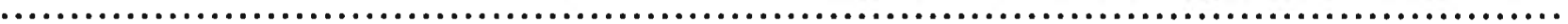

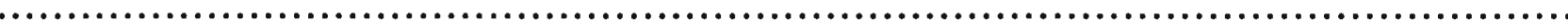

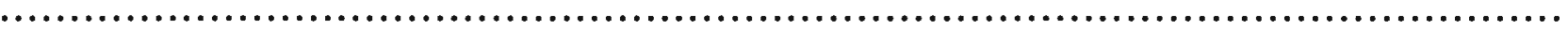
743

TAAAACTGTCCAGCTAGAGTCTTGTAGAGGGGGGTAGAATCCAGGTGTAGCGGTGAAATGCGTAGAGATCTGGAGGAATACCGGTGGCGAAGGCGGCCCCCTGGACAAAGA

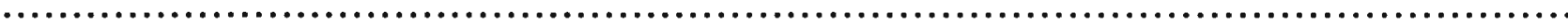

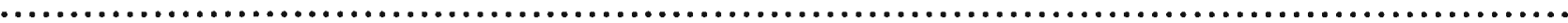
. $\ldots \ldots \ldots \ldots \ldots \ldots \ldots \ldots \ldots \ldots \ldots \ldots \ldots \ldots \ldots \ldots \ldots \ldots \ldots \ldots \ldots \ldots \ldots \ldots \ldots \ldots \ldots \ldots \ldots \ldots \ldots \ldots \ldots \ldots \ldots \ldots \ldots \ldots \ldots \ldots \ldots \ldots \ldots \ldots \ldots \ldots$. $\ldots \ldots \ldots \ldots \ldots$

CTGACGCTCAGGTGCGAAAGCGTGGGGAGCAAACAGGATTAGATACCCTGGTAGTCCACGCCGTAAACGATGTCGATTTGGAGGCTGTGTCCTTGAGACGTGGCTTCCGGAO

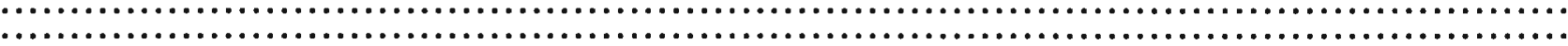

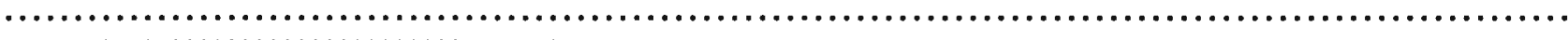

CTAACGCGTTAAATCGACCGCCTGGGGAGTACGGCCGCAAGGTTAAAACTCAAATGAATTGACGGGGGCCCGCACAAGCGGTGGAGCATGTGGTTTAATTCGATGCAACGCU

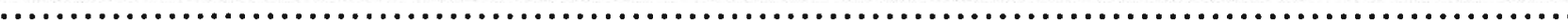

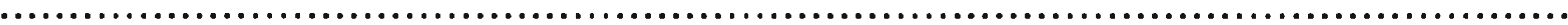
.$\ldots \ldots \ldots \ldots \ldots \ldots \ldots \ldots \ldots \ldots \ldots \ldots \ldots \ldots \ldots \ldots \ldots \ldots \ldots \ldots \ldots \ldots \ldots \ldots \ldots \ldots \ldots \ldots \ldots \ldots \ldots \ldots \ldots \ldots \ldots \ldots \ldots \ldots \ldots \ldots \ldots \ldots \ldots \ldots \ldots \ldots \ldots \ldots \ldots \ldots \ldots \ldots$

AAGAACCTTACCTGGCCTTGACATGTCTGGAATCCTGTAGAGATACGGGAGTGCCTTCGGGAATCAGAACACAGGTGCTGCATGGCTGTCGTCAGCTCGTGTCGTGAGATGT

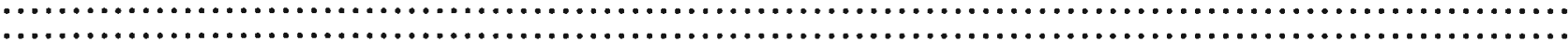

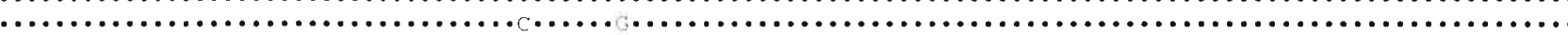
$\ldots$

TGGGTTAAGTCCCGCAACGAGCGCAACCCCTGTCCTTTGTTGCCAGCACGTAATGGTGGGAACTCAAGGGAGACTGCCGGTGATAAACCGGAGGAAGGTGGGGATGACGTCA

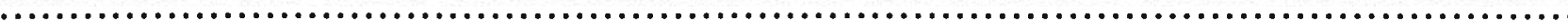

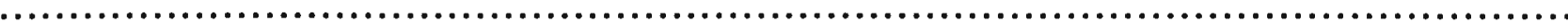
$\ldots \ldots \ldots \ldots \ldots \ldots \ldots \ldots \ldots \ldots \ldots \ldots \ldots \ldots \ldots \ldots \ldots \ldots \ldots \ldots \ldots \ldots \ldots \ldots \ldots \ldots \ldots \ldots \ldots \ldots \ldots \ldots \ldots \ldots \ldots \ldots \ldots \ldots \ldots \ldots \ldots \ldots \ldots \ldots \ldots \ldots \ldots \ldots \ldots \ldots \ldots \ldots \ldots \ldots \ldots \ldots \ldots \ldots$ 1303 AGTCATCATGGCCCTTACGGCCAGGGCTACACACGTGCTACAATGGCGCGTACAGAGGGCTGCAAGCTAGCGATAGTGAGCGAATCCCAAAAAGCGCGTCGTAGTCCGGATC

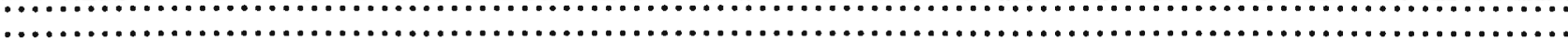

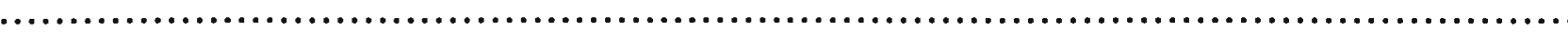

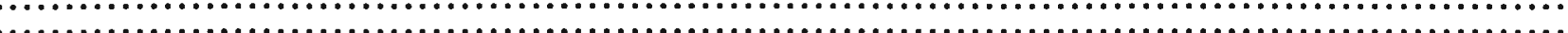

GGAGTCTGCAACTCGACTCCGTGAAGT GGGAATCGCTAGTAATCGCGAATCAGAATGTCGCGGTGAATACGTTCCCGGGCCTTGTACACACCGCCCGTCACACCATGGGAGT

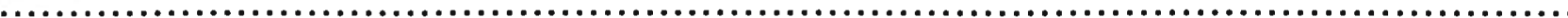

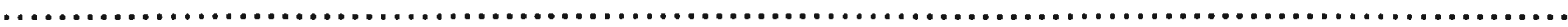

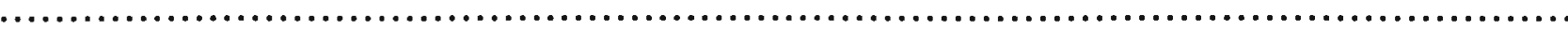


strains are clearly very closely related in terms of shared ancestry, falling well within the $3 \%$ SSU rRNA gene sequence variation proposed as a provisional species delineator (Stackebrandt \& Goebel 1994). This analysis shows that, although individual phenetic traits may show variation, in phylogenetic terms all the strains examined show insufficient SSU IRNA gene sequence variation to allow the identification of separately evolving subtaxa within the species Aeromonas salmonicida.

Acknowledgements. J.M.T. was supported by Forbairt and National University of Ireland, Gaiway postgraduate fellowships. This work was supported in part by CEC Contract AIR3-CT94-1884 and BioResearch Ireland.

\section{LITERATURE CITED}

Austin B, Austin DA, Dalsgaard I, Gudmundsdottir BK, Hoie S, Thornton JM, Larsen JL, O'hIci B, Powell R (1998) Characterization of atypical Aeromonas salmonicida by different methods. System Appl Microbiol 21:50-64

Austin DA, McIntosh D, Austin B (1989) Taxonomy of fish associated Aeromonas spp., with the description of Aeromonas salmonicida subsp. smithia subsp. nov. Syst Appl Microbiol 11:277-290

Griffin PJ, Snieszko SF, Friddle SB (1953) A more comprehensive description of Bacterium salmonicida. Trans Am Fish Soc 82:129-138

Higgins DG, Sharp PM (1988) CLUSTAL: a package for performing multiple sequence alignments on a micro-computer. Gene 73:237-244

Kimura T (1969) A new subspecies of Aeromonas salmonicida as an etiological agent of furunculosis on 'Sakuramasu'

Editorial responsibility: Larry Vaughan, Arlington, Massachusetts, USA
(Oncorhynchus masou) and pink salmon (O. gorbusha) rearing for maturity. Part 2. On the morphological and physiological properties. Fish Pathol 3:45-52

Lane DJ (1991) 16S/23S rRNA sequencing. In: Stackebrandt E, Goodfellow M (eds) Nucleic acid techniques in bacterial systematics. John Wiley \& Sons, New York, p 115-175

Martinez-Murcia AJ, Benlloch S, Collins MD (1992) Phylogenetic interrelationships of members of the genera Aeromonas and Plesiomonas as determined by $16 \mathrm{~S}$ ribosomal DNA sequencing: lack of congruence with results of DNADNA hybridizations. Appl Environ Microbiol 42:412-421

Paterson WD, Douey D, Desautels D (1980) Relationships between selected strains of typical and atypical Aeromonas salmonicida, Aeromonas hydrophila, and Haemophilus piscium. Can J Microbiol 26:588-598

Schubert RHW (1974) Genus II. Aeromonas Kluyer and van Niel 1936. In: Buchanan RE, Gibbons NE (eds) Bergey's manual of determinative bacteriology, 8 th edn. Williams and Wilkins, Baltimore, p 345-348

Smith IW (1963) The classification of Bacterium salmonicida. J Gen Microbiol 33:263-274

Snieszko SF (1957) Genus IV. Aeromonas Kluyer and van Niel 1936. In: Breed RS, Murray EGD, Smith NR (eds) Bergey's manual of determinative bacteriology, $7 \mathrm{th}$ edn. Williams and Wilkins, Baltimore, p 189-193

Snieszko SF, Griffin P, Friddle SB (1950) A new bacterium (Haemophilus piscium n. sp.) from ulcer diseases of trout. J Bacteriol 59:699-701

Stackebrandt E, Goebel BM (1994) Taxonomic note: a place for DNA-DNA reassociation and 16S rRNA sequence analysis in the present species definition in bacteriology. Int $J$ Syst Bacteriol 44:846-849

Trust TJ, Ishiguro EE, Atkinson HM (1980) Relationship between Haemophilus piscium and Aeromonas salmonicida revealed by Aeromonas hydrophila bacteriophage. FEMS Microbiol Lett 9:199-201

Woese CR (1987) Bacterial evolution. Microbiol Rev 51: $221-271$

Submitted: August 28, 1998; Accepted: November 24, 1998 Proofs received from author(s): January 12, 1999 